\title{
Repurchase Intention Among Ghanaian Online Consumers: Perceived Shopping Value Approach
}

\author{
Samuel Antwi* \\ School of Management and E-Business, Zhejiang Gongshang University, Hangzhou, P.R. China \\ samantwi88@outlook.com \\ Randy Kwaku Amponsah \\ School of Economics and Management Yangtze University, Jingzhou, Hubei P.R. China \\ ramponsah17@gmail.com
}

\begin{abstract}
With the rise in technology and the influx of diverse goods and services readily available on the internet today, online shopping has become an everyday thing in the global space through the use of technology-based channels like smartphones, tablets, laptops and others alike. Despite the incidence and daily growth this global phenomena, not all counties or parts of the world have been able to fully grasp the idea and use it to their benefit. A good example being Ghana, although close to $50 \%$ of the population has access to the internet as of January 2020 (DataReportal 2020) with about 15.1 million smartphone devices (Omondi 2020) many Ghanaians prefer traditional marketing to electronic commerce (e-commerce). With the above being noted, it is of no doubts that the online shopping community in Ghana is one that requires attention and retention by online goods and service providers. Making it a daunting task on online goods and service providers to focus on ways maintain this market and equally figure out ways to get on board new customers. This is in line with Shin et al. (2013), who asserted that online shopping behavior involves encouraging an online consumer to purchase and repurchase a product from the same online retailer. Many researchers, authors and marketers have researched factors that influence an online consumer's repurchases intention. This study has therefore been done after a look into past and existing literature which to a degree suggests that there hasn't been research conducted in the area of online consumers' repurchase intention from the same online retailer.
\end{abstract}

Keywords: Online Shopping, E-commerce, Repurchase Intention, Consumer Behavior, Ghana

DOI: $10.7176 / \mathrm{EJBM} / 13-8-01$

Publication date: April $30^{\text {th }} 2021$

\subsection{Introduction}

The increasing penetration rate of the internet globally has fueled online shopping. Online shopping is possible because of the availability of the internet, smartphones, tablets, iPad or laptop, and an online shopping platform. These days, online consumers can receive the products they buy in a cross-border e-commerce platform a few days because of massive logistics systems improvement. To the online retailer, online shopping goes beyond an online consumer just purchasing a product. This is because they may be several online retailers selling the same or similar goods and services. These online retailers compete for the same online consumers.

Consequently, they ensure that they put in proper strategies to retain their customers. In Ghana, e-commerce activities are still in the developmental stages, although close to $50 \%$ of the population has access to the internet as of January 2020 (DataReportal 2020) with about 15.1 million smartphone devices (Omondi 2020). Although many Ghanaians prefer traditional marketing, revenue generated from e-commerce in Ghana is projected at US\$453 million in 2020, a 46.5\% increase from the previous year. The Fashion Industry is projected to have the largest market segment, with a market volume of US\$144 million. The report further revealed that the number of e-commerce users in Ghana is projected to be 6.6 million people, a 19.3\% increment from the previous year. It can be deduced from the report that all things being equal, all the online retailers, both in Ghana and abroad, do compete among themselves for the 6.6 million e-commerce users. While some Ghanaian consumers shop in an online shopping platform onetime, other user continue to shop online.

As such, online retailers focus on ways to maintain their existing customers while coming out with ways to get new online consumers. This is in line with Shin et al. (2013), who asserted that online shopping behavior involves encouraging an online consumer to purchase and repurchase a product from the same online retailer. Many researchers, authors and marketers have researched factors that influence an online consumer's repurchase intention. According to the literature obtained (Aren et al. 2013; Ariffin et al. 2016; Wu et al. 2014; Zhang et al. 2011), perceived ease-of-use, perceived usefulness, trust, enjoyment, green value, emotional value, environmental conscious, perceived quality, perceived value, transaction cost, perceived website usability, perceived expertise in order fulfillment, perceived reputation, distrust in vendor behavior, relationship quality and site quality are factors that influence repurchase intention of online consumers.

This study was developed based on the past literature. To the best of our knowledge and literature, no research 
has been conducted in Ghana on the factors that influence an online consumer's intention to purchase from the same online retailer. Again, several factors can influence an online consumer to repurchase from the same online retailer; however, we focused on reputation, perceived usefulness, and after delivery service, with perceived shopping value serving as a mediator. Hence, the purpose of the research was to examine how reputation, perceived usefulness and after delivery services influence Ghanaian online consumer repurchase intention in an online shopping platform while mediated by perceived shopping value. The paper is structured as follows. The concept model and research hypothesis are presented next, followed by the research methods. The data analysis and discussion of the results are then followed. Finally, the researcher ended by presenting the conclusion and recommendations, highlighting the main findings and their implications for practice.

\subsection{Research Model and Hypothesis}

\subsection{Reputation}

Reputation is a general belief or perception that online consumers have about an online shopping platform. A firm reputation has the potential to influence their success. According to Barnett et al. (2006), reputation is a perceived attribute that differentiates a business from another business. To Gotsi and Wilson (2001), reputation takes a long time to build and manage. They added that it mostly relies on the daily perception that the public has of the firm activities. For an online shopping platform to build a good reputation, they must establish a stronger relationship with their customers (Walsh and Beatty 2007), and over time, they may turn loyal customers. A good reputation denotes that the public or online consumers see an online shopping platform to be good because their product offerings are of good quality, offer better customer service, and they modestly do business than other shopping platforms (Helm 2013; Hess 2008; Highhouse et al. 2009; Walsh and Beatty 2007). This may be based on their (online consumers) shopping experiences on the platform word of mouth from others. Research has shown that a good reputation helps an online shopping platform win trust and make their customers loyal (Caruana and Ewing 2010; Keh and Xie 2009). This can help the platform have a stronger competitive advantage than the others (Keh and Xie 2009; Walsh and Beatty 2007), reduce customer risks and increase their shopping behavior (Chun 2005). Again, reputation is found to have a stronger relationship with customer satisfaction and their commitment to a firm (Su et al. 2016), which subsequently influences their behavioral intention. The research also aimed to find the relationship between an online shopping platform's reputation and perceived shopping value. Thus;

H1: Reputation of an online shopping platform has a significant influence on perceived shopping value

H2: Reputation of an online shopping platform has a significant positive influence on repurchase intention.

\subsection{Perceived Usefulness}

An online consumer's perceived usefulness explains their assessment of a product they intend to purchase from an online shopping platform. Furthermore, Davis et al. (1989) defined perceived usefulness as the extent to which a user believes that using a particular system would improve their performance. Thus, it measures the extent to which an online consumer perceives how their involvement in an online shopping would enhance their performance. Davis (1989) suggested that the power to attract and retain online consumers in an online shopping platform relies significantly on technology's usefulness. Perceived usefulness tends to influence an online consumer's behavioral intention in an online shopping platform. This is evident from the works of (Alalwan et al. 2018; Gong et al. 2013; Shuhaiber and Mashal 2019). Also, the research finds the relationship between perceived usefulness and perceived shopping value. Hence, we proposed;

H3: Perceived usefulness has a significant positive influence on perceived shopping value

H4: Perceived usefulness has a significant positive influence on repurchase intention

\subsection{After Delivery Services}

After delivery service in online shopping involves the delivery of products purchased such as returns, product exchanges and refunds (Grewal et al. 2004), which may be a full refund or a partial refund. Kalia (2017) added order cancellation as a critical issue with regards to after delivery services. Although most e-commerce platforms have taken steps to eliminate these uncertainties that a consumer may have in mind, a customer may not have a real experience of it until they such a problem. Thus, they find themselves in a situation where they have to cancel their order and apply for a refund or receive another product. The action of retailers or online shopping platforms towards their customers in such situations can influence the trust and confidence they (online consumers) have for them. Thus, an online consumer will have a higher satisfaction towards a brand or a retailer if they provide a better condition for product return and exchange (Park et al. 2012) and hence, influence their behavior intention. Such conditions, (Javed \& Wu, 2020) reported are the provision of accurate information about the time required, process and completion of a return of goods, exchange of goods and refund of monies paid. The research would also find the relationship between after delivery service and an online consumer's perceived shopping value. Hence, we hypothesize;

H5: After delivery services have a significant positive influence on perceived shopping value 
H6: After delivery services have a significant positive influence on repurchase intention

\subsection{Perceived Shopping Value}

A customer's perceived shopping value explains their assessment of utility or satisfaction derived from their purchases. The evaluation is based on their perceived expectations and the actual product. It represents the difference in benefit a consumer receives from a product purchased and the given cost (Dlačić et al. 2013). Thus,

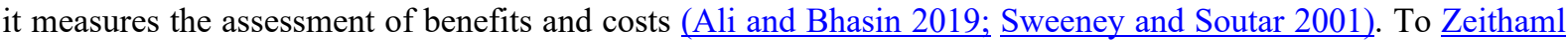
(1988), it is the difference between what online consumers think they have given up or the sacrifice made against what they have received or the benefit from goods purchased from an e-commerce platform. The definition implies that if an online consumer receives a net benefit or gain from an online shopping platform, they are likely to repurchase the same products from the platform in the future. This claim conforms with Ali and Bhasin (2019), Kim et al. (2012), and Zeithaml (2002), who found that perceived shopping value influences online consumers' intention to repurchase. Hence, we proposed;

H7: Perceived shopping value has a significant positive influence on repurchase intention

\subsection{Mediating Role of Perceived Shopping Value}

The research also seeks to find whether perceived shopping value will have a mediating effect between the factors that influence repurchase intention and repurchase intention. As such, we propose that;

H8: Perceived shopping value mediates the relationship between reputation, perceived usefulness and after delivery services and repurchase intention among Ghanaian online consumers

\subsection{Repurchase Intention}

For an online consumer to repurchase from the same brand or e-commerce platform, they should be satisfied with their initial purchases in most cases. Repurchase intention is an online consumer's decision to buy again from the same seller in the future (Chen and Chen 2017; Wilson and Keni 2018). It is regarded as a consideration that an online consumer considers to repurchase a particular product (Moslehpour et al. 2017). Consequently, online consumers must pay critical attention to their consumers' repurchase intention because of the saturated nature of the market. Thus, different retailers or shopping platforms sell the same or similar products, which provides an array of opportunities to consumers. Park and Kim (2003) added that online consumers usually have a strong passion for repurchasing from the same retailer if they find value and satisfaction with their previous purchase. The framework is shown in figure 1 attempts to explain the relationship between reputation, perceived usefulness, and after delivery service on a customer repurchase intention with perceived shopping value serving as a mediator.

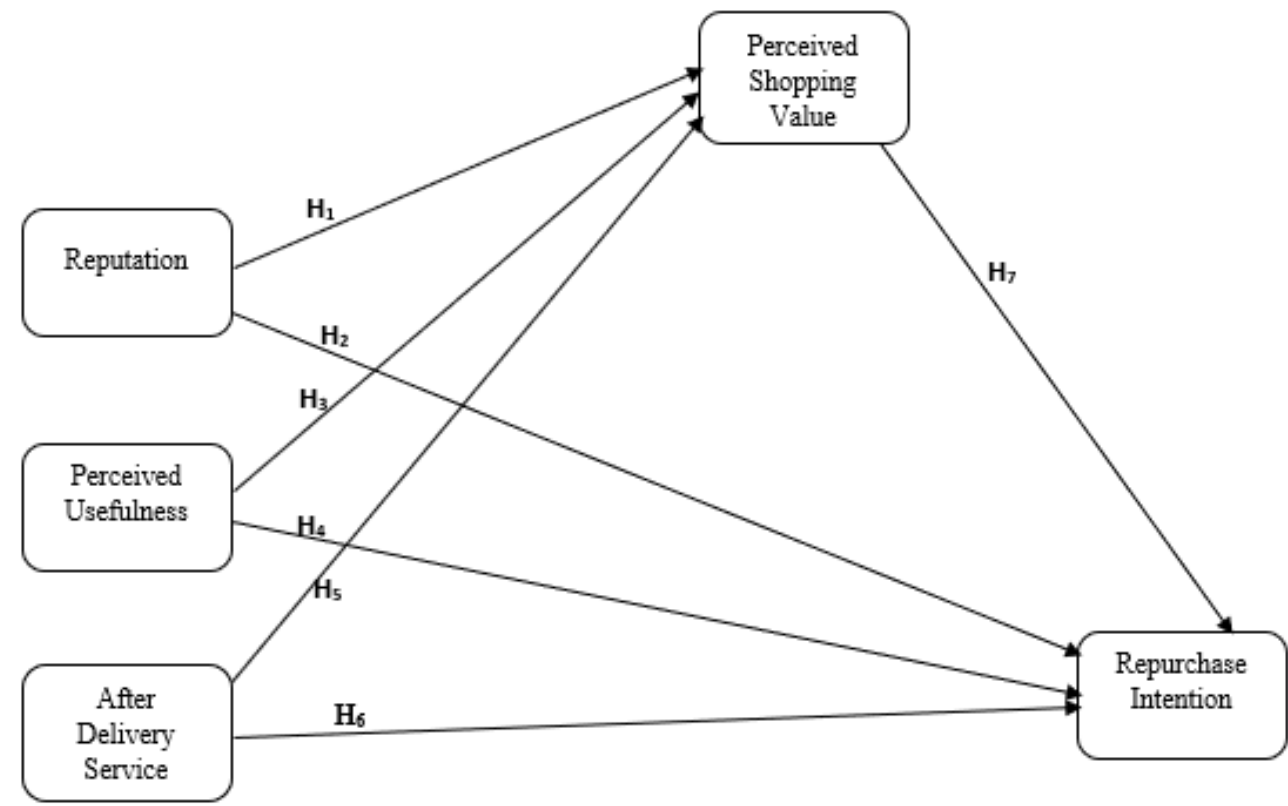

Figure 1: Research Model

\subsection{Research Methods}

\subsection{Measurement Items}

The data for the study was a primary source. Consequently, the researcher employed a questionnaire to obtain data 
from the subjects. The model for the study was made up of five constructs. Reputation, perceived usefulness and after delivery service served as the independent variables. Perceived shopping value served as the mediator, and repurchase intention served as the study's dependent variable. All the measurement items were adapted from past studies (Davis et al. 1989; Jarvenpaa et al. 1999; Javed and Wu 2020; Kim and Lennon 2013; Wu et al. 2014).

The first drafted questionnaire was first reviewed by three Doctoral students. The feedback received from them was used to revise the questionnaire. The purpose of this was to assess the content validity and clarity of the research instrument. The questionnaire was in two sections. The first section of the questionnaire was devoted to the background information of the subjects. The second section was devoted to the five constructs on a sevenpoint Likert scale, of which 1 represented Strongly Disagree, and 7 represented Strongly Agree.

\subsection{Data Collection}

Data was collected via an online survey with the help of Microsoft Forms. The researcher employed Microsoft Forms because it is very familiar with the targeted population. A convenience sampling technique was used to select the participants or subjects for the study. The researcher generated a link to access and fill the questionnaire on Google Forms. The generated link, together with the study's purpose, was sent to the participant via WhatsApp messenger and email. During the six weeks for data collection (December 1 to January 8, 2021), a total of three hundred and sixty-three responses were received. The subjects participated in the study in their freewill.

\subsection{Data Analysis}

We analyzed the respondents' background information using SPSS version 26. The measurement model and the structural model were assessed using the bootstrapping method embedded in Smart PLS 3.2.9.

\subsection{Background Information of Respondents}

Table 1 Descriptive Measurement of Demographic Variables $(\mathrm{N}=363)$

\begin{tabular}{|c|c|c|c|}
\hline Variables & Items & Frequency & $\%$ \\
\hline \multirow{2}{*}{ Gender } & Male & 173 & 47.7 \\
\hline & Female & 190 & 52.3 \\
\hline \multirow{4}{*}{ Age } & Below 20 & 17 & 4.7 \\
\hline & $20-25$ & 104 & 28.7 \\
\hline & $26-30$ & 163 & 44.9 \\
\hline & Above 30 & 79 & 21.8 \\
\hline \multirow{5}{*}{ Online Shopping Experience (years) } & Below 1 & 42 & 11.6 \\
\hline & $1-3$ & 95 & 26.2 \\
\hline & $4-6$ & 125 & 34.4 \\
\hline & $7-10$ & 78 & 21.5 \\
\hline & Above 10 & 23 & 6.3 \\
\hline \multirow{5}{*}{ Occupation } & Student & 73 & 20.1 \\
\hline & Public Sector & 72 & 19.8 \\
\hline & Private Sector & 127 & 35.0 \\
\hline & Self-employed & 80 & 22.0 \\
\hline & Unemployed & 11 & 3.0 \\
\hline \multirow{5}{*}{ Level of Education } & Senior High School & 16 & 4.4 \\
\hline & Diploma & 60 & 16.5 \\
\hline & Degree & 210 & 57.9 \\
\hline & Masters & 60 & 16.5 \\
\hline & $\mathrm{PhD}$ & 17 & 4.7 \\
\hline
\end{tabular}

Note: $\mathrm{N}=$ Sample size and $\%=$ Percentage

Table 1 presented the descriptive measurement of the demographic variables of the respondents. Of the 363 respondents received at the end of the data collection period, more than half were females $(52.3 \%)$, and the remaining were males $(47.7 \%)$. In terms of age, the majority of the respondents were between the age range of 26$30(44.9 \%)$, followed by $20-25$ years $(28.7 \%)$, above 30 years $(21.8 \%)$ and lastly, below 20 years $(4.7 \%)$. Concerning their online shopping experience, most of the respondents had 4-6 years of shopping experience (34.4\%), followed by $1-3$ years of experience $(26.2 \%), 7-10$ years $(21.5 \%)$, below $1(11.6 \%)$ and over 10 years of the shopping experience $(6.3 \%)$. Also, most of the respondents worked in the private sector $(35.0 \%)$, followed by self-employment $(22.0 \%)$, and then students $(20.1 \%)$, public sector $(19.8 \%)$ and lastly unemployed $(3.0 \%)$. Concerning their level of education, over half of the respondents had a Degree (57.9\%), with Diploma (16.5\%) and Masters (16.5\%) having the same percentage and then $\mathrm{PhD}(4.7 \%)$ and finally Senior High School Certificate $(4.4 \%)$. 


\subsection{Measurement Model}

Table 2 Reliability and Variability Constructs (Confirmatory Factor Analysis)

\begin{tabular}{|c|c|c|c|c|}
\hline Latent Variables & Loadings & $\mathrm{CR}$ & AVE & $\alpha$ \\
\hline $\begin{array}{l}\text { Reputation } \\
\text { RU1 }\end{array}$ & 0.828 & & & \\
\hline RU2 & 0.800 & & & \\
\hline RU3 & 0.865 & 0.907 & 0.711 & 0.864 \\
\hline RU4 & 0.878 & & & \\
\hline $\begin{array}{l}\text { Perceived Usefulness } \\
\text { PU1 }\end{array}$ & 0.891 & & & \\
\hline PU2 & 0.898 & 0.923 & 0.800 & 0.875 \\
\hline PU3 & 0.894 & & & \\
\hline $\begin{array}{l}\text { After Delivery Services } \\
\text { ADS1 }\end{array}$ & 0.887 & & & \\
\hline ADS2 & 0.874 & 0.920 & 0.794 & 0.870 \\
\hline ADS3 & 0.911 & & & \\
\hline $\begin{array}{l}\text { Perceived Shopping Value } \\
\text { PSV1 }\end{array}$ & 0.826 & & & \\
\hline PSV2 & 0.854 & & & \\
\hline PSV3 & 0.853 & 0.908 & 0.711 & 0.864 \\
\hline PSV4 & 0.839 & & & \\
\hline $\begin{array}{l}\text { Repurchase Intention } \\
\text { RPI1 }\end{array}$ & 0.891 & & & \\
\hline RPI2 & 0.893 & 0.921 & 0.796 & 0.872 \\
\hline RPI3 & 0.892 & & & \\
\hline
\end{tabular}

Note: Sample size $(\mathrm{N})=363, \mathrm{CR}=$ Composite Reliability, AVE $=$ Average Variance Extracted, $\alpha=$ Cronbach's Alpha, RU $=$ Reputation, PU = Perceived Usefulness, ADS = After Delivery Services, PSV = Perceived Shopping Value, RPI $=$ Repurchase Intention

We assessed the validity of the data according to Nunnally and Bernstein (1994) and Fornell and Larcker (1981) criteria. Thus, from Table 2, both the composite reliability and the Cronbach alpha of all the constructs exceed the threshold of 0.7 (see Table 2), indicating that the items are valid. For convergent validity, the average variance extracted (AVE) for each construct (see Table 2) was greater than the threshold of 0.5 (Hu et al. 2004). Additionally, each of the measurements' loading was statistically significant (see Table 2) and ranged from 0.800 to 0.911. Concerning discriminant validity, the square roots of the AVEs were greater than all the cross-correlations (see Table 3), indicating a good discriminant validity (Fornell and Larcker 1981).

Table 3 Fornell-Larcker Discriminant Validity

\begin{tabular}{|l|c|c|c|c|c|}
\hline Variables & RU & PU & ADS & PSV & RPI \\
\hline RU & 0.843 & & & & \\
\hline PU & 0.787 & 0.894 & & & \\
\hline ADS & 0.740 & 0.795 & 0.891 & & \\
\hline PSV & 0.743 & 0.779 & 0.788 & 0.843 & \\
\hline RPI & 0.744 & 0.764 & 0.744 & 0.819 & 0.892 \\
\hline
\end{tabular}

Note: Values in bold are square root of AVE, RU = Reputation, $\mathrm{PU}=$ Perceived Usefulness, ADS = After Delivery Services, PSV $=$ Perceived Shopping Value, RPI $=$ Repurchase Intention

\subsection{Structural Model}

The structural model was evaluated to determine the t-value and the path coefficient's significance corresponding to the hypothesis. The structural model in SEM-PLS shows the relationships between the latent variables based on the study's conceptual framework. The analysis was done using the bootstrap resampling function embedded in the SmartPLS version 3.2.9. The mediation hypothesis was also assessed using the bootstrapping method as recommended by (Preacher and Hayes 2008). The path coefficient or original sample of the constructs had a standardized value that ranges from -1 to 1 . The closer the estimated coefficients are to 1 , the stronger the relationship and the closer it is to 0 , the weaker the relationship. Observation of the path coefficient in Table 4 shows a positive relationship among all the constructs although the magnitude of the effect varies. The results of the hypothesis testing are presented in Table 4.

The results from Table 4 indicates that most of our hypothesis was supported. For instance, reputation (RU) was found to have a significant positive influence on repurchase intention (RPI) as (OS $=0.186$, $t$-value $=3.455$ and $\mathrm{p}$-value $<0.01$ ). On the other hand, perceived usefulness (PU) had a significant positive influence on perceived 
shopping value $(\mathrm{PSV})$ as $(\mathrm{OS}=0.293, \mathrm{t}$-value $=4.348$ and $\mathrm{p}$-value $<0.01)$. Similarly, after delivery service $(\mathrm{ADS})$ was found to have a significant positive influence on perceived shopping value (PSV) as (OS $=0.387$, t-value $=$ 7.810 and $p$-value $<0.01)$. However, after delivery service (ADS) did not have a significant influence on repurchase intention $(\mathrm{RPI})$ as $(\mathrm{OS}=0.098$, $\mathrm{t}$-value $=1.810$ and $\mathrm{p}$-value $>0.05)$.

A mediation analysis was conducted with perceived shopping value to gain a more comprehensive understanding of the research model. The results in Table 4 further revealed that perceived shopping value mediates the relationship between all the independent variables (reputation, perceived usefulness and after delivery services) on repurchase intention. For example, perceived shopping value (PSV) mediates the relationship between perceived usefulness (PU) and repurchase intention (RPI) as $(\mathrm{OS}=0.136$, t-value $=3.605$ and $\mathrm{p}$-value $<0.01)$.

Table 4. Path Coefficients and Specific Indirect Effect of the structural Model Constructs

\begin{tabular}{|l|l|l|l|l|l|l|}
\hline Constructs Effects & OS & SM & STDEV & T-Value $(|\mathrm{O} / \mathrm{STDEV}|)$ & P-values & Conclusion \\
\hline RU - PSV & 0.227 & 0.226 & 0.059 & 3.838 & $0.000^{* * *}$ & Supported \\
\hline RU - RPI & 0.186 & 0.183 & 0.054 & 3.455 & $0.001^{* * *}$ & Supported \\
\hline PU - PSV & 0.293 & 0.290 & 0.067 & 4.348 & $0.000^{* * *}$ & Supported \\
\hline PU - RPI & 0.179 & 0.177 & 0.059 & 3.030 & $0.003^{* * *}$ & Supported \\
\hline ADS - PSV & 0.387 & 0.391 & 0.050 & 7.810 & $0.001^{* * *}$ & Supported \\
\hline ADS - RPI & 0.098 & 0.098 & 0.054 & 1.810 & 0.071 & Not Supported \\
\hline PSV - RPI & 0.464 & 0.468 & 0.059 & 7.873 & $0.000^{* * *}$ & Supported \\
\hline RU - PSV - RPI & 0.105 & 0.105 & 0.030 & 3.541 & $0.000^{* * *}$ & Supported \\
\hline PU - PSV - RPI & 0.136 & 0.136 & 0.038 & 3.605 & $0.000^{* * *}$ & Supported \\
\hline ADS - PSV - RPI & 0.180 & 0.182 & 0.031 & 5.728 & $0.000^{* * *}$ & Supported \\
\hline
\end{tabular}

Note: $* * *$ p-value $<0.01, * *$ p-value $<0.05$, OS $=$ Original Sample, SM $=$ Sample Mean, STDEV $=$ Standard Deviation, RU = Reputation, PU = Perceived Usefulness, ADS = After Delivery Services, PSV = Perceived Shopping Value, RPI = Repurchase Intention

\subsection{Discussion and Contributions}

\subsection{Discussion}

The study aimed to find the influence of reputation, perceived usefulness, and delivery services on Ghanaian online consumer repurchase intention while mediated by perceived shopping value. First, reputation (RU) can influence online consumers' decision-making process regarding their repurchase. Thus, reputation (RU) is not only able to influence repurchase intention (RPI) among Ghanaian online consumers but had a positive and significant influence on perceived shopping value (PSV). It can be deduced from the findings that a good reputation will lead to a positive repurchase intention among Ghanaian online consumers. A good reputation implies that the public sees online shopping to be good because their product offerings are good in addition to a better customer service (Helm 2013; Hess 2008; Highhouse et al. 2009; Walsh and Beatty 2007), which subsequently helps them win the trust and loyalty of their customers (Caruana and Ewing 2010; Keh and Xie 2009).

Similarly, perceived usefulness (PU) had a significant positive effect on perceived shopping value (PSV) and repurchase intention (RPI). Perceived usefulness can predict an individual intention to use new technology (Venkatesh et al. 2003). Thus, it deals with the extent to which an individual believes that their involvement in online shopping would improve their performance, and Ghanaian online consumers believe that it would have a positive and significant influence on their perceived shopping value and intention to repurchase. The findings confirm the works (Alalwan et al. 2018; Gong et al. 2013; Shuhaiber and Mashal 2019).

Moreover, after delivery services (ADS) had a significant and positive effect on perceived shopping value (PSV) but had no effect on repurchase intention (RPI). The findings imply Ghanaian online consumer intention to repurchase had no relationship with the online retailer's after-delivery services. The finding is very surprising as all things being equal, online consumers would be mindful of an online retailer's post-delivery services. A possible explanation for this may be that Ghanaian online consumers are satisfied with all their online purchases and may not require any post-delivery services. This contrasts with Park et al. (2012) work that online consumers will have a higher satisfaction if a retailer provides a condition for product return and package. 


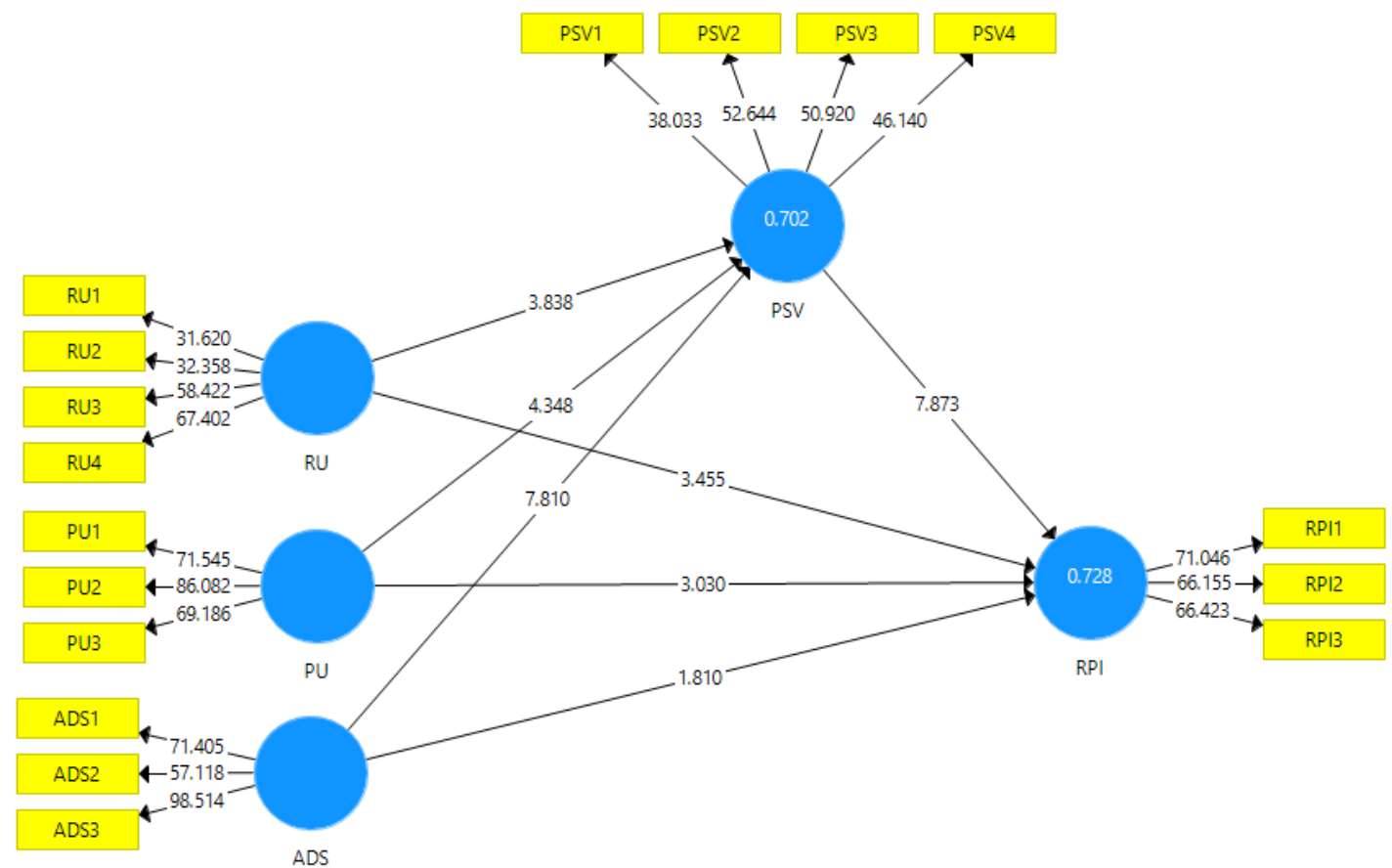

Figure 2: Research Model

Perceived shopping value (PSV) was found to have a significant and positive effect on repurchase intention (RPI). Thus, if the net effect of shopping online is positive, it would influence Ghanaian online consumers' decision to repurchase. The net effect is the difference between the benefits and costs associated with the transaction. This is predictable as most consumers would want to achieve value for money on their online purchases. Our work is the same as (Ali and Bhasin 2019; Kim et al. 2012; Zeithaml 2002).

Lastly, perceived shopping value (PSV) significantly mediates the relationship between reputation (RU) and repurchase intention (RPI), perceived usefulness (PU) and repurchase intention (RPI) and also between after delivery service and repurchase intention (RPI). Thus, the relationship between reputation and repurchase intention is significantly influenced by the presence of perceived shopping value. At the same time, the presence of perceived shopping value significantly influences the relationship between perceived usefulness and repurchase intention, likewise the relationship between after delivery service and repurchase intention.

\subsection{Contributions for Research}

Our study examined the role of reputation, perceived usefulness and after delivery service on repurchase intention among online consumers in Ghana. The study contributes to academics by adding up to the few works that have been conducted in Ghana. Thus, it will help to understand repurchase intention in online shopping in the Ghanaian context. Again, this is one of the few research types that use perceived shopping value as the mediating effect between reputation, perceived usefulness and after delivery services on repurchase intention. To the best of our knowledge and literature, no much work has been done using perceived shopping value in our context.

\subsection{Contributions for Practice}

Our research findings suggest that an online retailer or e-commerce platform's reputation will influence repurchase intention on the part of Ghanaian online consumers. It takes a long time to build a reputation, but it can easily be destroyed within a very few period. As such, online retailers or e-commerce platforms should strive to achieve and maintain a good reputation. A good reputation can be earned and sustained if the online retailer or e-commerce platform offers a good product, excellent delivery and post-delivery services and an effective customer service. Perceived usefulness and shopping value can influence a consumer's decision to repurchase. Perceived usefulness and shopping value are subjective nature, and it varies among online consumers. However, online retailers or ecommerce platforms ought to ensure that their customers have a good shopping experience. This is because a good shopping experience, quality website interface, excellent payment system, customer service, and others add to the benefits they derived from online shopping. Although after delivery service did not affect repurchase intention, an online retailer or e-commerce platform needs to provide after delivery service in place as it can affect their reputation in the long run.

\subsection{Conclusion}

The study aimed at examining the role of reputation, perceived usefulness and after delivery service on online 
consumers in Ghana repurchase intention in an online shopping platform. As such, a hypothesis was raised and tested. Although the empirical results contribute to both research and practice, there were some limitations. First, the study was skewed to only one geographical location. Thus, the study was conducted in Ghana, and as such, the findings may not hold in some geographical areas. Also, there may be several factors that can influence an online consumer's intention to repurchase from an online retailer or e-commerce platform, but the study focused on only three factors. Future studies should dive into other factors that can influence a decision to repurchase from an online retailer or e-commerce platform. Lastly, we did not employ longitudinal in our study. Because customer behavior changes over time, we suggest that future studies use longitudinal technique consideration to confirm if the findings would remain the same.

Funding: This research was entirely funded by the authors.

Disclosure Statement: The authors declare no conflict of interest.

\section{References}

Alalwan, A. A., Baabdullah, A. M., Rana, N. P., Tamilmani, K., \& Dwivedi, Y. K. (2018). Examining adoption of mobile internet in Saudi Arabia: Extending TAM with perceived enjoyment, innovativeness and trust. Technology in Society, 55, 100-110. https://doi.org/10.1016/j.techsoc.2018.06.007

Ali, A., \& Bhasin, J. (2019). Understanding Customer Repurchase Intention in E-commerce: Role of Perceived Price, Delivery Quality, and Perceived Value. Jindal Journal of Business Research, 8(2), 142-157. https://doi.org/10.1177/2278682119850275

Aren, S., Güzel, M., Kabadayı, E., \& Alpkan, L. (2013). Factors Affecting Repurchase Intention to Shop at the Same Website. Procedia - Social and Behavioral Sciences, 99, 536-544. https://doi.org/10.1016/j.sbspro.2013.10.523

Ariffin, S., Yusof, J. M., Putit, L., \& Shah, M. I. A. (2016). Factors Influencing Perceived Quality and Repurchase Intention Towards Green Products. Procedia Economics and Finance, 37(16), 391-396. https://doi.org/10.1016/s2212-5671(16)30142-3

Barnett, M. L., Jermier, J. M., \& Lafferty, B. A. (2006). Corporate Reputation: The Definitional Landscape. Corporate Reputation Review, 9(1), 26-38. https://doi.org/10.1057/palgrave.crr.1550012

Caruana, A., \& Ewing, M. T. (2010). How corporate reputation, quality, and value influence online loyalty. Journal of Business Research, 63(9-10), 1103-1110. https://doi.org/10.1016/j.jbusres.2009.04.030

Chen, C. C. V., \& Chen, C. J. (2017). The role of customer participation for enhancing repurchase intention. Management Decision, 55(3), 547-562. https://doi.org/10.1108/MD-06-2016-0380

Chun, R. (2005). Corporate reputation: Meaning and measurement - Chun - 2005 - International Journal of Management Reviews - Wiley Online Library. International Journal of Management Reviews, 7(2), 91-109. https://doi.org/10.1111/j.1468-2370.2005.00109.x

DataReportal. (2020). Digital 2020 Global Digital Overview. In Hootsuite, We Are Social. https://datareportal.com/reports/digital-2020-global-digital-overview

Davis, F. D. (1989). Perceived usefulness, perceived ease of use, and user acceptance of information technology. MIS Quarterly: Management Information Systems, 13(3), 319-339. https://doi.org/10.2307/249008

Davis, F. D., Bagozzi, R. P., \& Warshaw, P. R. (1989). User Acceptance of Computer Technology: A Comparison of Two Theoretical Models. Management Science, 35(8), 982-1003. https://doi.org/10.1287/mnsc.35.8.982

Dlačić, J., Arslanagić, M., Kadić-Maglajlić, S., Marković, S., \& Raspor, S. (2013). Exploring perceived service quality, perceived value, and repurchase intention in higher education using structural equation modelling. Total Quality Management and Business Excellence, 25(1-2), 141-157. https://doi.org/10.1080/14783363.2013.824713

Fornell, C., \& Larcker, D. F. (1981). Evaluating Structural Equation Models with Unobservable Variables and Measurement Error. Journal of Marketing Research, 18(1), 39-50. https://doi.org/10.1177/002224378101800104

Gong, W., Stump, R. L., \& Maddox, L. M. (2013). Factors influencing consumers' online shopping in China. Journal of Asia Business Studies, 7(3), 214-230. https://doi.org/10.1108/JABS-02-2013-0006

Gotsi, M., \& Wilson, A. M. (2001). Corporate reputation: Seeking a definition. Corporate Communications: An International Journal, 6(1), 24-30. https://doi.org/10.1108/13563280110381189

Grewal, D., Iyer, G. R., \& Levy, M. (2004). Internet retailing: Enablers, limiters and market consequences. Journal of Business Research, 57(7), 703-713. https://doi.org/10.1016/S0148-2963(02)00348-X

Helm, S. V. (2013). How corporate reputation affects customers' reactions to price increases. Journal of Revenue and Pricing Management, 12(5), 402-415. https://doi.org/10.1057/rpm.2013.12

Hess, R. L. (2008). The impact of firm reputation and failure severity on customers' responses to service failures. Journal of Services Marketing, 22(5), 385-398. https://doi.org/10.1108/08876040810889157

Highhouse, S., Brooks, M. E., \& Gregarus, G. (2009). An organizational impression management perspective on 
the formation of corporate reputations. Journal of Management, 35(6), 1481-1493. https://doi.org/10.1177/0149206309348788

Hu, X., Lin, Z., Whinston, A. B., \& Zhang, H. (2004). Hope or hype: On the viability of escrow services as trusted third parties in online auction environments. Information Systems Research, 15(3), 236-249. https://doi.org/10.1287/isre.1040.0027

Jarvenpaa, S. L., Tractinsky, N., \& Saarinen, L. (1999). Consumer Trust in an Internet Store: A Cross-Cultural Validation. Journal of Computer-Mediated Communication, 5(2). https://doi.org/10.1111/j.10836101.1999.tb00337.x

Javed, M. K., \& Wu, M. (2020). Effects of online retailer after delivery services on repurchase intention: An empirical analysis of customers' past experience and future confidence with the retailer. Journal of Retailing and Consumer Services, 54(September), 101942. https://doi.org/10.1016/j.jretconser.2019.101942

Kalia, P. (2017). Service quality scales in online retail: methodological issues. International Journal of Operations \& Production Management, 37(2), 226-255. https://doi.org/10.1108/IJOPM-03-2015-0133

Keh, H. T., \& Xie, Y. (2009). Corporate reputation and customer behavioral intentions: The roles of trust, identification and commitment. Industrial Marketing Management, 38(7), $732-742$. https://doi.org/10.1016/j.indmarman.2008.02.005

Kim, C., Galliers, R. D., Shin, N., Ryoo, J.-H., \& Kim, J. (2012). Factors influencing Internet shopping value and customer repurchase intention. Electronic Commerce Research and Applications, 11(4), 374-387. https://doi.org/10.1016/j.elerap.2012.04.002

Kim, J., \& Lennon, S. J. (2013). Effects of reputation and website quality on online consumers' emotion, perceived risk and purchase intention: Based on the stimulus-organism-response model. Journal of Research in Interactive Marketing, 7(1), 33-56. https://doi.org/10.1108/17505931311316734

Moslehpour, M., Wong, W. K., Van Pham, K., \& Aulia, C. K. (2017). Repurchase intention of Korean beauty products among Taiwanese consumers. Asia Pacific Journal of Marketing and Logistics, 29(3), 569-588. https://doi.org/10.1108/APJML-06-2016-0106

Nunnally, J. C., \& Bernstein, I. H. (1994). Psychometric theory (3rd ed.). McGraw-Hill. https://www.worldcat.org/title/psychometric-theory/oclc/28221417

Omondi, G. (2020). The state of mobile in Ghana's tech ecosystem. https://www.gsma.com/mobilefordevelopment/blog/the-state-of-mobile-in-ghanas-techecosystem/\#: :text=As of the third quarter,(as of Q3 2019).

Park, C. H., \& Kim, Y. G. (2003). Identifying key factors affecting consumer purchase behavior in an online shopping context. International Journal of Retail \& Distribution Management, 31(1), 16-29. https://doi.org/10.1108/09590550310457818

Park, I., Cho, J., \& Rao, H. R. (2012). The effect of pre- and post-service performance on consumer evaluation of online retailers. Decision Support Systems, 52(2), 415-426. https://doi.org/10.1016/j.dss.2011.10.001

Preacher, K. J., \& Hayes, A. F. (2008). Asymptotic and resampling strategies for assessing and comparing indirect effects in multiple mediator models. Behavior Research Methods, 40(3), 879-891. https://doi.org/10.3758/BRM.40.3.879

Shin, J. I., Chung, K. H., Oh, J. S., \& Lee, C. W. (2013). The effect of site quality on repurchase intention in Internet shopping through mediating variables: The case of university students in South Korea. International Journal of Information Management, 33(3), 453-463. https://doi.org/10.1016/j.ijinfomgt.2013.02.003

Shuhaiber, A., \& Mashal, I. (2019). Understanding users' acceptance of smart homes. Technology in Society, 58(January), 101110. https://doi.org/10.1016/j.techsoc.2019.01.003

Su, L., Swanson, S. R., Chinchanachokchai, S., Hsu, M. K., \& Chen, X. (2016). Reputation and intentions: The role of satisfaction, identification, and commitment. Journal of Business Research, 69(9), 3261-3269. https://doi.org/10.1016/j.jbusres.2016.02.023

Sweeney, J. C., \& Soutar, G. N. (2001). Consumer perceived value: The development of a multiple item scale. Journal of Retailing, 77(2), 203-220. https://doi.org/10.1016/S0022-4359(01)00041-0

Venkatesh, V., Morris, M. G., Davis, G. B., \& Davis, F. D. (2003). User Acceptance of Information Technology: Toward a Unified View. MIS Quarterly, 27(3), 425-478. https://doi.org/10.2307/30036540

Walsh, G., \& Beatty, S. E. (2007). Customer-based corporate reputation of a service firm: Scale development and validation. Journal of the Academy of Marketing Science, 35(1), 127-143. https://doi.org/10.1007/s11747007-0015-7

Wilson, N., \& Keni, K. (2018). Pengaruh Website Design Quality Dan Kualitas Jasa Terhadap Repurchase Intention: Variabel Trust Sebagai Variabel Mediasi. Jurnal Manajemen Dan Pemasaran Jasa, 11(2), 291. https://doi.org/10.25105/jmpj.v11i2.3006

Wu, L. Y., Chen, K. Y., Chen, P. Y., \& Cheng, S. L. (2014). Perceived value, transaction cost, and repurchaseintention in online shopping: A relational exchange perspective. Journal of Business Research, 67(1), 27682776. https://doi.org/10.1016/j.jbusres.2012.09.007 
Zeithaml, V. A. (1988). Consumer perceptions of price, quality, and value: a means-end model and synthesis of evidence. Journal of Marketing, 52(3), 2-22. https://doi.org/10.1177/002224298805200302

Zeithaml, V. A. (2002). Service excellence in electronic channels. Managing Service Quality: An International Journal, 12(3), 135-139. https://doi.org/10.1108/09604520210429187

Zhang, Y., Fang, Y., Wei, K. K., Ramsey, E., McCole, P., \& Chen, H. (2011). Repurchase intention in B2C ecommerce - A relationship quality perspective. Information and Management, 48(6), 192-200. https://doi.org/10.1016/j.im.2011.05.003 